Sains Malaysiana 46(1)(2017): 117-122

http://dx.doi.org/10.17576/jsm-2017-4601-15

\title{
Effects of Different Doses of Fertilizers on Growth and Yield Components of Biodiesel Plant (Jatropha curcas L.)
}

(Kesan Dos Baja Berbeza ke atas Pertumbuhan dan Komponen Hasil Tumbuhan Biodiesel (Jatropha curcas L.))

\author{
InAM Ali SHAH, SUlTAN MEHMOD WAZIR \& RAHMAT ALI KHAN*
}

\begin{abstract}
Effects of different doses of fertilizers on growth and yield components of biodiesel plant (Jatropha curcas L.), was made in the prevailing environment of University of Science and Technology Bannu. The experiment was carried out in randomized complete block design (RCBD) with three replications. Nitrogen, phosphorus and potassium were applied in the form of urea, single super phosphate and potash in the shape of combined NPK, respectively, during sprouting of leaves and thereafter with each irrigation in split doses. The analysis of variance for number of branches per plant showed significant results indicated in ANOVA. Significantly the number of primary branches per plant 8.07 was recorded in T4 with the application of dose of (N P K: $2507.5 \mathrm{gm}: 1091.5 \mathrm{gm}: 501.5 \mathrm{gm}$ ). Maximum No. of secondary branches per plant (9.100) were recorded in T1 especially at both plots. Flower per inflorescence showed that maximum value (122.810) was recorded in $T 5$ of especially at both plots. Inflorescence plant ${ }^{-1}$ showed that maximum value (39.477) were recorded in $T 1$ and minimum value were noted as (12.733) at T3 on both the flats. The data for fruits per plant showed that maximum value (143.300) was recorded in T1. The seed index, which was the output of the aim of this research work, reflects highly significant differences in mean value observed for both subplots. Mean values showed that maximum seeds weight 45.86 was recorded in T1 of especially at both plots while low seed index was noted as 22.84 at T5 (N: 3400 gm, P: $1480 \mathrm{gm}, \mathrm{K}: 680 \mathrm{gm})$ at both the subplots.
\end{abstract}

Keywords: Bannu; biodiesel plant; NPK; UST

\section{ABSTRAK}

Kesan daripada dos baja yang berbeza ke atas komponen pertumbuhan dan hasil tumbuhan biodiesel (Jatropha curcas L.) dibuat dalam persekitaran semasa di Universiti Sains dan Teknologi Bannu. Penyelidikan telah dijalankan dalam reka bentuk blok lengkap ( $R C B D)$ dengan tiga replikasi. Nitrogen, fosforus dan kalium diaplikasikan dalam bentuk urea, super fosfat tunggal dan potas masing-masing dalam bentuk gabungan NPK, semasa daun bercambah dan selepas itu dalam setiap pengairan dengan dos berbeza. Analisis varians bagi bilangan dahan setiap tumbuhan menunjukkan hasil yang dinyatakan dalam ANOVA. Bilangan paling ketara untuk dahan setiap tumbuhan 8.07 direkodkan pada T4 dengan penggunaan dos (N P K: $2507.5 \mathrm{gm}: 1091.5 \mathrm{gm}: 501.5 \mathrm{gm}$ ). Bilangan maksimum dahan sekunder setiap tumbuhan (9.100) direkodkan pada T1 untuk kedua-dua petak. Bunga untuk setiap perbungaan menunjukkan nilai maksimum (122.810) direkodkan pada T5 untuk kedua-dua petak. Tumbuhan perbungaan menunjukkan nilai maksimum (39.477) telah direkodkan pada T1 dan nilai minimum dicatat sebagai (12.733) pada T3 ke atas kedua-dua dataran. Data untuk buah-buahan setiap tumbahan menunjukkan nilai maksimum (143.300) direkodkan pada T1. Indeks benih yang merupakan output matlamat penyelidikan ini, menunjukkan perbezaan ketara untuk nilai min yang diperhatikan pada kedua-dua subpetak. Nilai min menunjukkan berat maksimum 45.86 direkodkan pada T1 untuk kedua-dua petak manakala indeks biji benih minimum telah direkod sebagai 22.84 pada 75 ((N:3400 gm, P: 1480 gm, K: 680 gm) untuk kedua-dua subpetak.

Kata kunci: Bannu; NPK; tumbuhan biodiesel; UST

\section{INTRODUCTION}

Jatropha curcas L. belongs to Kingdom: Plantae, Class: Angiosperma, Order: Malpighiales, Family: Euphorbiaceae, Subfamily: Crotonoideae and Tribe: Jatropheae. The name Jatropha derived from Greek word 'iatro', meaning 'physician', and 'trophe', meaning 'nutrition, commonly named as physic nut'. It belongs to family Euphorbiaceae having 175 succulent plants, including trees and shrubs. Mature plants produce separate male and female flowers. It is resistant to drought and pests. It contains highly toxic compounds. It produces seeds containing $27-40 \%$ oil, averaging $34.4 \%$. After oil extraction the remaining press cake of seeds could also be considered for energy production. None of the Jatropha species have been properly domesticated. Rajagopal and Zilberman (2007) reported that the demand for plant-based feedstock for biodiesel production has received much attention in recent years due to green energy policy vis- 
$\grave{a}$-vis blending requirements of diesel adopted by many countries. However, as a result of despite their abundance use as oil and reclamation plants and their productivity is variable, and the long-term impact of their large-scale use on soil quality and the environment is unknown. Igbinosa et al. (2009) demonstrated potential broad spectrum antimicrobial activity of J. curcas. However, the current seed biomass output of Jatropha for production of biofuels is inadequate to completely replace fossil fuels (Ruth 2008). Despite growing advocacy for Jatropha for large-scale cultivation, its systematic yield improvement studies, especially the nutritional requirements of the crop in marginal lands of tropical agro climatic conditions have not been adequately addressed.

In recent years, Jatropha curcas L., has received considerable interest of the researchers as a potential source of non-edible vegetable oil. Its multifarious benefits as a source of green manure, soil ameliorator and improve rural economy by generating huge manpower employment during various stages of its cultivation and downstream processing makes it a potential candidate for large-scale plantation on marginal lands (Abdelgadir et al. 2007; Sunil et al. 2008; Rao et al. 2008; Kochhar et al. 2008; Kheira \& Atta 2009; Mishra 2009; Behera et al. 2010). European Union and India have set targets of 10 and $20 \%$ replacement of transport fossil fuel with biodiesel by 2020 and 2012, respectively (Rosch \& Skarka 2009; Biswas et al. 2010). Jatropha curcas L. has the possible potential of providing an alternate source of bio fuel which may be exploited because it has physicochemical properties matching with diesel fuel. Khimani et al. (2003) concluded that use of $20 \mathrm{~g}$ urea, $120 \mathrm{~g}$ SSP and $16 \mathrm{~g}$ MOP to each pit at the time of planting of Jatropha and thereafter an application of 46:48:24 kg N:P:K ha-1 was recorded as optimum.

Although plant growth and yield is considerably influenced by application of inorganic fertilizers, striking a balance between increased yields attributes and use of optimum level of Nitrogen. Phosphorus and Potassium is critical for Jatropha to advance as a marketable crop. As a result, the present study was undertaken to estimate the effect of different combinations of N, P and $\mathrm{K}$ fertilizers on development, growth, oil content and seed yield of Jatropha in prevailing environment of University of Science and Technology, Bannu.

\section{MATERIALS AND METHODS}

A field experiment was designed to evaluate the 'Effects of Different Doses of NPK based Fertilizers on Growth and Yield Components of (Jatropha curcas L.) on Site-Sandy Loam Soil during 2012' to study the response of Jatropha curcas L., to nitrogen, phosphorus and potassium level in the environment of Bannu. Details of the materials and methods used and the techniques which were adopted during the course of investigation are described below.

\section{DESIGN AND LAYOUT}

A field experiment of transplanted stumps with roots of Biodiesel plant, Jatropha curcas L., was laid out in a Randomized Complete Block Design with 15 treatments combinations keeping one absolute control and will be replicated three times. The data was recorded and analyzed. The brief sketch is highlighted as;

$\begin{array}{ll}\text { Replications } & =03 \\ \text { Treatment combinations } & =(04+01) \\ \text { Row to row distance } & =(1.8 \mathrm{~m}) \\ \text { Plant to plant distance } & =(1.8 \mathrm{~m}) \\ \text { Total number of sub plots } & =5 \text { per replication } \\ \text { Size of Sub plot } & =8.1 \times 6.4 \mathrm{~m}\end{array}$

\section{STATISTICAL ANALYSIS}

The data regarding different plant parameters was averaged and subjected to statistical manipulation for the analysis of variance techniques to establish the level of variability among different block treatments of plants (Steel \& Torri 1980).

\section{FERTILIZER APPLICATIONS}

Nitrogen, phosphorus and potassium were applied (in the form of urea, single super phosphate and potash in the shape of combined NPK, respectively, during sprouting of leaves and, thereafter with each irrigation in split doses.

$\begin{array}{lllrr}\text { T1 } & \text { Control } & & & \\ \text { T2 } & \text { NPK: } & 1912.5 \mathrm{gm}: & 1832.5 \mathrm{gm}: & 382.5 \mathrm{gm} \\ \text { T3 } & \text { NPK: } & 2210.0 \mathrm{gm}: & 962.0 \mathrm{gm}: & 442 \mathrm{gm} \\ \text { T4 } & \text { NPK: } & 2507.5 \mathrm{gm}: & 1091.5 \mathrm{gm}: & 501.5 \mathrm{gm} \\ \text { T5 } & \text { NPK: } & 2805.0 \mathrm{gm}: & 1221.5 \mathrm{gm}: & 561 \mathrm{gm}\end{array}$

\section{PARAMETERS}

Data was recorded on the parameters like number of primary branches plant ${ }^{-1}$, number of secondary branches plant $^{-1}$, number of flowers plant ${ }^{-1}$, number of inflorescence plant $^{1}$, number of fruits plant ${ }^{-1}$, number of seeds fruit ${ }^{-1}, 100$ seeds weight and seed yield acre ${ }^{-1}$.

\section{RESULTS AND DISCUSSION}

The results of the crop of Jatropha of Bio-Diesel Project is highlighted in tables and exposed with the help of graphic's figures. The analysis of variance for the traits concerned has been shown in Tables 1(a) to 5(a) while the mean values are shown in Tables 1 to 5 of the parameters recorded. Moreover, the mean data is well highlighted in graphic representations as shown in Figures 1 to 5. The average values of these ten plants under the following parameters were considered for further analysis and their achieved results are discussed as follows: 
TABLE 1 . Table of mean values of primary branches per plant

\begin{tabular}{cccc}
\hline Treatment & S1 (Subplot) & S2 (Subplot) & Means \\
\hline T1 & 6.67 & 9.2 & 7.93 \\
T2 & 8.17 & 7.1 & 7.63 \\
T3 & 6.03 & 7.17 & 6.6 \\
T4 & 8.53 & 7.6 & 8.07 \\
T5 & 6.63 & 5.33 & 5.98 \\
Mean & 7.2 & 7.28 & \\
\hline
\end{tabular}

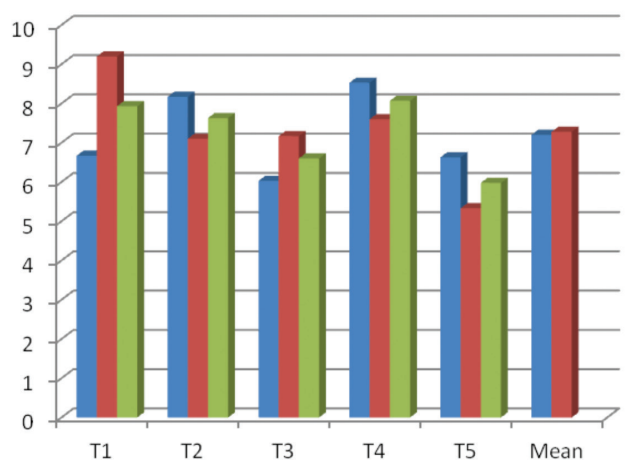

- S1 (Subplot)

- S2 (Subplot)

Means

FIGURE 1. Graphic presentation of effects of NPK of primary branches per plant

\section{NUMBER OF PRIMARY BRANCHES PLANT ${ }^{-1}$}

Significantly the higher mean of number of branches per plant 8.07 was recorded in T4 with the application of dose of (NPK: $2507.5 \mathrm{gm}$ : $1091.5 \mathrm{gm}$ : $501.5 \mathrm{gm}$ ). Nevertheless minimum number of branches per plant with the mean value of 5.98 was recorded at T5 with the concentration of (NPK: $2805 \mathrm{gm}: 1221 \mathrm{gm}: 561 \mathrm{gm}$ ) in case of number of branches per plant as shown in Table 1 . These observations are logically in full conformity with those reported by Venugopal (2006). Figure 1 clearly indicates the significant results.

\section{NO. OF SECONDARY BRANCHES PLANT ${ }^{-1}$}

The analysis of variance for number of secondary branches per plant reflects significant differences in mean value observed for both subplots. The results are fairly in agreement with those reported by Dinesh et al. (2001). The table of means (Table 2) showed that maximum number of secondary branches per plant (9.100) were recorded in T1 (Control) of especially at both plots. Despite the fact that minimum number of secondary branches per plant were noted as 5.533 at T5 (NPK: 3952 gm: 1924 gm: 884 gm) at both the flats. Figure 2 of graphic presentations clearly indicates the significant results.

\section{FLOWER PER INFLORESCENCE}

The analysis of variance for flower per inflorescence reflects significant differences in mean value observed
TABLE 2. Number of secondary branches per plant

\begin{tabular}{cccc}
\hline Treatment & S1 (Subplot) & S2 (Subplot) & Means \\
\hline T1 & 7.000 & 9.100 & 8.050 \\
T2 & 8.233 & 7.300 & 7.767 \\
T3 & 5.900 & 6.657 & 6.233 \\
T4 & 8.600 & 8.233 & 8.417 \\
T5 & 7.200 & 5.533 & 6.367 \\
Mean & 7.387 & 7.347 & \\
\hline
\end{tabular}

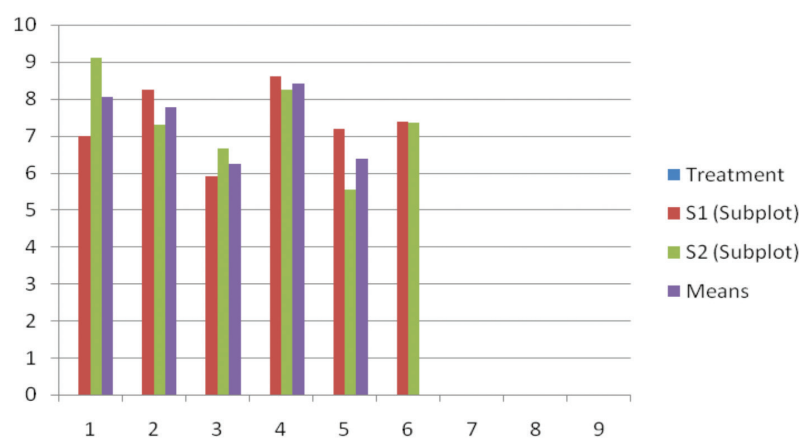

FIGURE 2. Graphic presentation of effects of NPK on No. of sec. branches plant ${ }^{-1}$

for both subplots. The results are fairly in agreement with those reported by Dinesh et al. (2001). The table of means (Table 3) showed that maximum flower per inflorescence (122.810) were recorded in T5 of especially at both plots. Despite the fact that minimum flower per inflorescence were noted as 64.810 at T4 at both the flats (Figure 3).

TABLE 3. Flower per inflorescence

\begin{tabular}{cccc}
\hline Treatment & S1 (Subplot) & S2 (Subplot) & Means \\
\hline T1 & 100.740. & 108.800 & 104.770 \\
T2 & 93.444 & 123.443 & 108.444 \\
T3 & 77.333 & 93.163 & 85.248 \\
T4 & 94.600 & 64.810 & 79.705 \\
T5 & 122.810 & 80.887 & 101.848 \\
Mean & 97.785 & 94.221 & \\
\hline
\end{tabular}

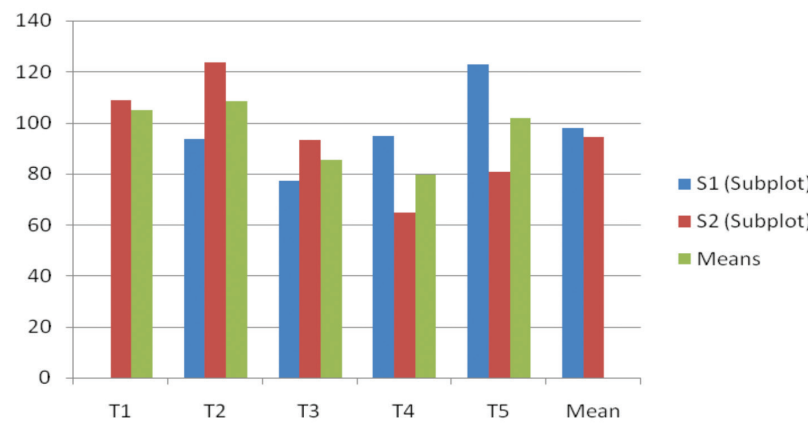

FIGURE 3. Graphic presentation of effects of NPK on flower per inflorescence 


\section{INFLORESCENCE PLANT ${ }^{-1}$}

The analysis of variance for inflorescence plant ${ }^{-1}$ reflects significant differences in mean value observed for both subplots. The results are fairly in agreement with those reported by Dinesh et al. (2001). Table 4 shows that maximum inflorescence plant ${ }^{-1}(39.477)$ were recorded in T1 (Control) of especially at both plots. Despite the fact that minimum inflorescence plant ${ }^{-1}$ were noted as 12.733 at T3 on both the flats (Figure 4).

TABLE 4. Infloresence per plant

\begin{tabular}{cccc}
\hline Treatment & S1 (SubploT) & S2 (Subplot) & Means \\
\hline T1 & 26.033 & 39.477 & 32.755 \\
T2 & 22.800 & 24.133 & 23.467 \\
T3 & 12.733 & 25.100 & 18.917 \\
T4 & 38.500 & 26.267 & 32.383 \\
T5 & 22.267 & 12.967 & 17.617 \\
Mean & 24.467 & 25.589 & \\
\hline
\end{tabular}

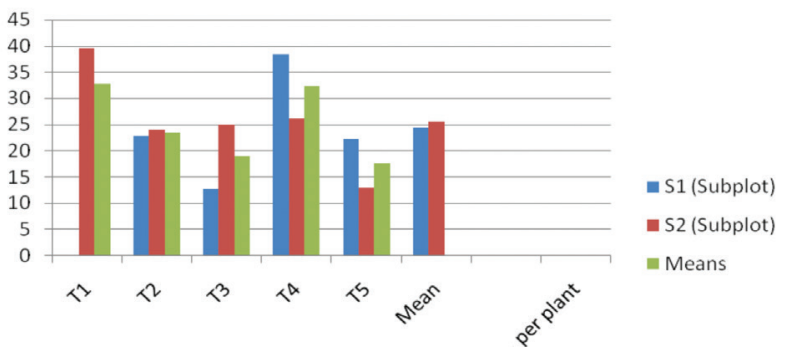

FIGURE 4. Graphic presentation of effects of NPK on infloresence per plant

\section{FRUITS PLANT}

The analysis of variance for fruits per plant reflects significant differences in mean value observed for both subplots. The results are fairly in agreement with those reported by Dinesh et al. (2001). The table of means (Table 5) showed that maximum fruits per plant (143.300) were recorded in T1 (Control) of especially at both plots. Despite the fact that minimum fruits per plant were noted as (30.167) at T3 for both the flats. Graphic presentations clearly indicates the significant results.

\section{SEED INDEX PLANT ${ }^{-1}$}

The analysis of variance for seed index plant ${ }^{-1}$ reflects significant differences in mean value observed for both subplots. The results are fairly in agreement with those reported by Dinesh et al. (2001). The table of means (Table $6)$ showed that maximum seed index plant $^{-1}(45.86)$ were recorded in T1 (Control) of especially at both plots. Despite the fact that minimum seed index plant $^{-1}$ were noted as 22.84 at T5 (NPK: 3952 gm: $1924 \mathrm{gm:} 884 \mathrm{gm}$ ) at both the flats. Figure 6 of graphic presentations clearly indicates the significant results.
TABLE 5. Fruit per plant

\begin{tabular}{cccc}
\hline Treatment & S1 (Subplot) & S2 (Subplot) & Means \\
\hline T1 & 30.200 & 143.300 & 86.750 \\
T2 & 101.633 & 70.667 & 86.150 \\
T3 & 50.867 & 30.167 & 40.517 \\
T4 & 97.333 & 87.367 & 92.350 \\
T5 & 55.267 & 48.767 & 52.017 \\
Mean & 67.060 & 76.053 & \\
\hline
\end{tabular}

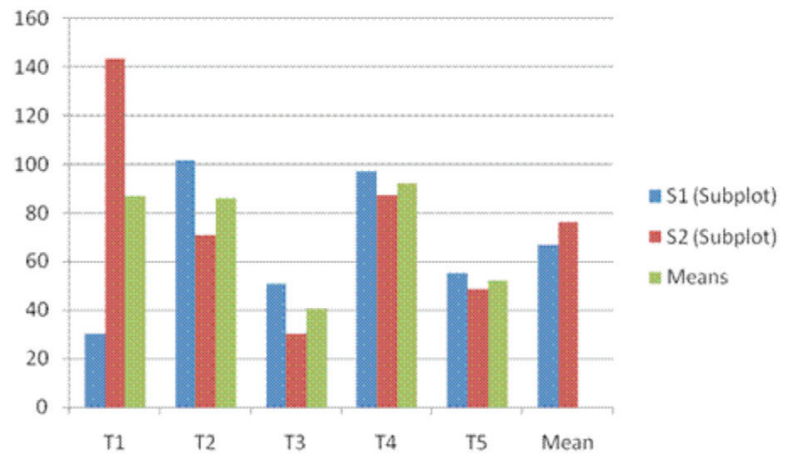

FIGURE 5. Graphic presentation of effects of NPK on fruit per plant

TABLE 6. Mean values of seed index per plant

\begin{tabular}{cccc}
\hline Treatment & S1 (Subplot) & S2 (Subplot) & Means \\
\hline T1 & 49.33 & 42.39 & 45.86 \\
T2 & 44.34 & 41.35 & 42.84 \\
T3 & 31.74 & 39.18 & 35.46 \\
T4 & 29.26 & 31.17 & 30.21 \\
T5 & 28.50 & 11.17 & 22.84 \\
Mean & 36.64 & 34.25 & \\
\hline
\end{tabular}

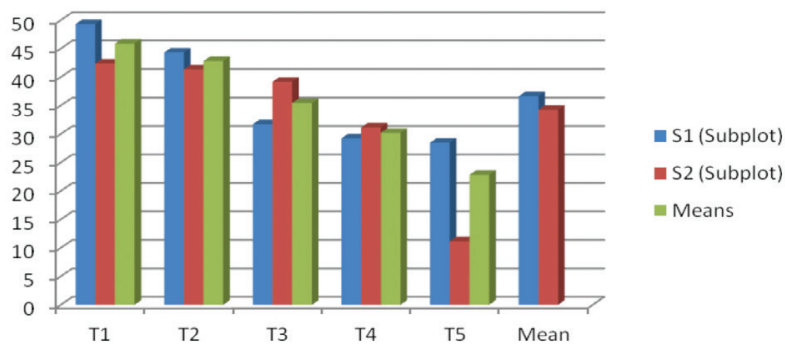

FIGURE 6. Graphic presentation of effects of NPK on seed index per plant

Anon (2003) found significance results on application of doses of $500 \mathrm{~g}$ SSP and $50 \mathrm{~kg}$ NPK $(15: 15: 15)$ to Jatropha. Higher shelling percentage (47.8\%) of Jatropha at 100:88 g urea: SSP plant ${ }^{-1}(54.5 \%)$ which was superior over 50:88 g urea: SSP plant ${ }^{-1}(51.9 \%)$ and 50:76 g urea: SSP plant ${ }^{-1}$ Anon (2005, 2004). Sasikala (2005) recorded $7500 \mathrm{~kg} \mathrm{ha}^{-1}$ dry seed yield with application of 20:120:20 kg urea, SSP and $\mathrm{MOP} \mathrm{ha}^{-1}$, respectively, to Jatropha. Joshi (2005) concluded 
that $\mathrm{N}: \mathrm{P}: \mathrm{K}$ should be applied in the ratio of $46: 48: 24 \mathrm{~kg}$ $\mathrm{ha}^{-1}$ to Jatropha in split doses from second year onwards so as to obtain higher yield. Venugopal (2006) in his studies conducted in Tamil Nadu on Jatropha indicated different doses of fertilizers for different soils. NPK at the rate of 60:40:20 kg ha-1 was found optimum for black soils. Rana et al. (2006) studied the effect of varied levels of nitrogen on seed yield of castor and found significant increase in seed yield with an increase in the nitrogen level between 0,60 and $120 \mathrm{~kg} \mathrm{~N} \mathrm{ha}^{-1}$. The highest was recorded in the treatment supplied with $120 \mathrm{~kg} \mathrm{~N}^{-1}$ (31.5 q ha-1). Patil and Parameshwarappa (2007) reported significantly higher seed yield of Jatropha at 80:80:80 kg N:P2O5:K2O ha-1 (1475 kg ha $\left.{ }^{-1}\right)$ which was superior over 40:40:40 kg N:P2O5:K2O ha ${ }^{-1}$ (450 kg ha-1) and 60:60:60 kg N:P2O5:K2O ha-1 (1000 kg ha-1) they also reported significantly higher plant height at 80:80:80 kg $\mathrm{N}: \mathrm{P} 2 \mathrm{O} 5: \mathrm{K} 2 \mathrm{O} \mathrm{ha}{ }^{-1}(2.53 \mathrm{~cm})$ and higher collar diameter of at 80:80:80 kg N: P2O5:K2O ha-1 $(36.08 \mathrm{~cm})$ over 40:40:40 kg N: P2O5:K2O ha ${ }^{-1}(36.00 \mathrm{~cm})$ and 60:60:60 $\mathrm{kg}$ N: P2O5:K2O ha-1 $(34.33 \mathrm{~cm})$. Yong et al. (2010) reported that the pooled analysis of the results indicated that the flowering phenomenon in Jatropha was earlier in N60 and N60 P80 treatments during the 1st and 2nd phase of flowering, respectively, as compared to other treatments. The results are in agreement with previous report in Jatropha where nitrogen at higher level hastened the flowering process.

\section{CONCLUSION AND RECOMMENDATIONS}

The seed index, which is the output of the aim of this research work, reflects highly significant differences in mean value observed for both subplots. Mean values showed that maximum seeds weight 45.86 were recorded in T1 (control) of especially at both plots. While low seed index was noted as 22.84 at T5 (N: 3400 gm, P: 1480 gm, $\mathrm{K}: 680 \mathrm{gm})$ at both the subplots. Flower per inflorescence showed that maximum value (122.810) was recorded in T5 of especially at both plots. Despite the fact that minimum flower per inflorescence were noted as (64.810) at T4 at both the flats. The table of means for fruits per plant showed that maximum value (143.300) were recorded in T1 (Control) of especially at both plots and minimum fruits per plant were noted as (30.167) at T3 both the flats. Inflorescence plant ${ }^{-1}$ showed that maximum value (39.477) were recorded in $\mathrm{T} 1$ and minimum value were noted as (12.733) at T3 on both the flats. Significantly the number of primary branches per plant 8.07 was recorded in T4 with the application of dose of (NPK: $2507.5 \mathrm{gm}$ : 1091.5 $\mathrm{gm}: 501.5 \mathrm{gm}$ ). The table of means showed that maximum number of secondary branches per plant (9.100) were recorded in $\mathrm{T} 1$ of especially at both plots. Despite the fact that minimum No. of secondary branches per plant were noted as (5.533) at T5 (NPK: 3952 gm: 1924 gm: 884 gm) at both the flats.

\section{REFERENCES}

Abdelgadir, H.A., Johnson, S.D. \& Staden, J.V. 2007. Promoting branching of a potential biofuel crop Jatropha curcas L. by foliar application of plant growth regulators. Plant Growth Regul. 58: 287-295.

Anonymous. 2003. Experience and observation on Jatropha plantation from 1986-2003. Proceedings of National Workshop, Pune, India, 5-8 August.

Anonymous. 2004. Biofuels: A strategy for enhanced water use efficiency improved livelihoods and protecting environment in the SAT. International Crop Research Institute for the Semi- Arid Tropics (ICRISAT), Patancheru, Andhra Pradesh, India. http://www/icrisat.org/Biopower/Wanietal Biofuels WUE Jan 2007.

Anonymous. 2005. Production Profile of Jatropha-The Bio-fuel. Department of Medicinal and Aromatic Plants, Collage of Horticulture, Arabhavi-591310.

Behera, S.K., Srivastava, P., Tripathy, R., Singh, J.P. \& Singh, N. 2010. Evaluation of plant performance of Jatropha curcas L. under diferent agro-practices for optimizing biomass -A case study. Biomass Bioener. 34: 30-41.

Biswas, P.K., Pohit, V. \& Kumar, R. 2010. Biodiesel from Jatropha: Can India meet the $20 \%$ blending target? Energy Policy 38: 1477-1484.

Dinesh, H., Dinesh, K.A. \& Sundaramoorthy, S. 2001,Appraisal of four castor varieties on the basis of different fertility levels and seed yield. Current Agric. 25(1-2): 123-125.

Igbinosa, O.O., Igbinosa, E.O. \& Aiyegoro, O.A. 2009. Antimicrobial activity and phytochemical screening of stem bark extracts from Jatropha curcas (Linn). African J. Pharm Pharmacol. 3(2): 058-062.

Joshi, V. 2005. Cultivation of non-traditional oilseed plant Jatropha curcas for utilization of forest wastelands. Ann. of For. 13(1): 59-62.

Kheira, A.A.A. \& Atta, N.M.M. 2009. Response of Jatropha curcas L. to water deficits: Yield, water use efficiency and oil seed characteristics. Biomass Bioener. 33: 1343-1350.

Khimani, R.A., Satodiya, B.N.\& Jadav, R.G. 2003. Cultivation aspects of Jatropha: An overview. Proceedings of National Workshop, Pune, India, 5-8 August.

Kochhar, S., Singh, S.P. \& Kochhar, V.K. 2008. Effect of auxins and associated biochemical changes during clonal propagation of the biofuel plant-Jatropha curcas. Biomass Bioener. 32: 1136-1143.

Mishra, D.K. 2009. Selection of candidate plus phenotypes of Jatropha curcas L. using method of paired comparisons. Biomass Bioener. 33: 542-545.

Patil, S.J. \& Parameshwarappa, K.G. 2007. Silvicultural management of jatropha (Jatropha curcas L.) under rainfed conditions. National Seminar on Changing Global Vegetable Oil Scenario: Issues and Challenges Before India, ISOR. pp. 371-372.

Rajagopal, D. \& Zilberman, D. 2007. Review of environmental, economic and policy aspects of biofuels policy. Research Working Paper Series 4341. The World Bank. pp. 1-107.

Rana, D.S., Giri, G. \& Pachauri, D.K. 2006. Evaluation of castor (Ricinus communis) genotypes for productivity, economics, litter fall and changes in soil properties under different levels of inter row spacing and nitrogen. Indian J. Agron. 5(4): 318-322. 
Rao, G.R., Korwar, G.R., Shanker, A.K. \& Ramakrishna, Y.S. 2008. Genetic associations, variability and diversity in seed characters, growth, reproductive phenology and yield in Jatropha curcas (L.) accessions. Trees 22: 697-709.

Rosch, C. \& Skarka, J. 2009. The European biofuels policy and sustainability. International Association for Energy Economics. pp. 31-35. iaee.org/documents/newsletterarticles/309rosch. pdf.

Ruth, L. 2008. Bio or bust? The economic and ecological cost of biofuels. EMBO-reports 9: 130-133.

Steel, R.G.D. \& Torrie, J.H. 1980. Principles and Procedures of Statistics: A Biometrical Approach. 2nd ed. New York: McGraw Hill. p. 633.

Sunil, N., Varaprasad, K.S., Sivaraj, N., Kumar, T.S., Abraham, B. \& Prasad, R.B.N. 2008. Accessing Jatropha curcas L. germplasm in-situ - A case study. Biomass Bioener. 32: 198-202.

Venugopal, R. 2006. Jatropha_Jatropha_Jatropha_. Kisan World, August-2006. pp. 22-23.
Inam Ali Shah \& Sultan Mehmod Wazir

Department of Botany

University of Science and Technology Bannu, KPK

Pakistan

Rahmat Ali Khan*

Department of Biotechnology

University of Science and Technology Bannu, KPK

Pakistan

*Corresponding author; email: rahmatgul_81@yahoo.com

Received: 22 March 2016

Accepted: 28 April 2016 